頭頸部癌手術での下顎骨再建

一自験 3 症例の検討 一

小島 正 ${ }^{1)} \cdot$ 石川 忠孝1) - 鈴木 敏夫 ${ }^{2}$

若島 純一3) 朝倉 光司 ${ }^{3)}$

\title{
Mandibular Reconstruction in Head and Neck Cancer Surgery
}

\author{
- Clinical Evaluation of Three Cases- \\ Tadashi Kojima and Tadataka Ishikawa \\ (Otaru City Hospital) \\ Toshio Suzuki \\ (Otaru Ear Clinic) \\ Junichi Wakashima and Kohji Asakura \\ (Sapporo Medical University)
}

\begin{abstract}
Recent advance in reconstructive surgery have made it possible to reconstruct a mandibular defect remaining after surgical resection for cancer. However, there are still many difficulties concerning the recovery of oral function following mandibular reconstruction. We attempted a different mandibular reconstruction method in three patients. The first patient was a 66 -year-old male with mesopharyngeal cancer. His mandibular defect was reconstructed by a free rib bone graft with a free rectus abdominis musculocutaneous flap. The second patient was a 55 -year-old male with tongue cancer. His mandibular defect was reconstructed using a free vascularized osteocutaneous scapular flap. The third patient was a 65 -year-old male with lower gingival cancer. His mandibular defect was reconstructed using a titanium mandibular reconstruction plate with a pedicled pectoris major musculocutaneous flap. All three patients were satisfied with their oral function following mandibular reconstruction. Thus, the mandibular reconstruction method should been selected with consideration of the patient's age and general condition.
\end{abstract}

Key words : mandibular reconstruction, free rib bone graft, rectus abdominis musculocutaneous flap, scapular osteocutaneous flap

はじめに

再建手術の進歩により，頭頸部癌の手術に捻いて，拡 大切除が可能となり, 下顎骨を合併切除する機会も近年 ふえてきた. Quality of Life の面からも, 咀嚼, 酀下,
構音は重要な位置を占めるが, これらの機能に関わる下 䫇骨の処理と再建に関して耳鼻科医からの報告は多くな い. 今回 3 症例の頭頸部癌切除に伴う下顎骨合併切除例 に対して異なる再建法を用いたが，過去の報告と併せて

1）市立小樽病院耳鼻咽喉科

2) おたるイアクリニック

3）札沅医科大学医学部耳鼻咽喉科学教室 
下㴿骨の再建法について検討してみた.

$$
\text { 症例(表 1, 図 1) }
$$

症例 1.66 歳, 男性.

中咽頭癌 T3N2bM0

平成 4 年10月より咽頭痛扣よび燕下痛を自覚していた.
11月中旬他医受診にて, 右扁桃の潰瘍性病変を指摘され 当科を紹介された. 同年11月30日初診し, 右扁桃㧊よび 前口蓋弓, 臼後三角部に広がる潰瘍を伴う腫瘍を認めた。 右顎下部と上頸部に可動性不良の $30 \mathrm{~mm}$ のリンパ節を 2 個触知した. 原発部の生検にて中分化型扁平上皮癌と 診断された。術前治療として同年12月11日より平成 5 年

表 1 症例一覧

会話機能は広瀬案 ${ }^{1)}$ 基準による。

\begin{tabular}{|c|c|c|c|c|}
\hline & & 症例 1 & 症例 2 & 症例 3 \\
\hline & 齢, 性 & 66, 男 & 55, 男 & 65 , 男 \\
\hline & 発部位 & 中咽頭 T 3 N 2 b M 0 & 舌 T3NOMO & 下歯肉 $\mathrm{T} 4 \mathrm{~N} 1 \mathrm{MO}$ \\
\hline $\begin{array}{l}\text { 方 } \\
\text { 法 }\end{array}$ & $\begin{array}{c}\text { 軟部組織 } \\
\text { 骨 } \\
\text { 骨固定 }\end{array}$ & $\begin{array}{c}\text { 腹直筋皮弁 } \\
\text { 遊離肋骨 } \\
\text { チタン下顎再建プレート }\end{array}$ & $\begin{array}{l}\text { 肩甲骨皮弁 } \\
\text { 同上 } \\
\text { チタンミニプレート }\end{array}$ & $\begin{array}{c}\text { 大胸筋皮弁(口腔，頸皮） } \\
\text { なし（骨架橋のみ） } \\
\text { チタン下顎再建プレート }\end{array}$ \\
\hline 結 & $\begin{array}{l}\text { 合併症 } \\
\text { 外見 }\end{array}$ & $\begin{array}{c}\text { なし } \\
\text { ほぼ満足 }\end{array}$ & $\begin{array}{l}\text { なし } \\
\text { 満足 }\end{array}$ & $\begin{array}{c}\text { プレート露出し再手術 } \\
\text { ほぼ満足 }\end{array}$ \\
\hline 果 & $\begin{array}{l}\text { 口腔機能 } \\
\text { 会話機能 }\end{array}$ & $\begin{array}{c}\text { 軽度開口障害, 軟菜食 } \\
5 \text { 点 }\end{array}$ & $\begin{array}{c}\text { 開口障害なし，軟菜食 } \\
8 \text { 点 }\end{array}$ & $\begin{array}{c}\text { 開口障害なし, 常食 } \\
9 \text { 点 }\end{array}$ \\
\hline
\end{tabular}

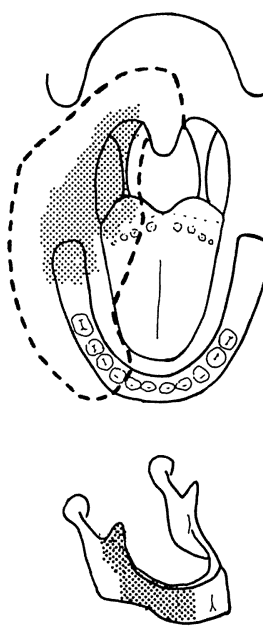

症例 1
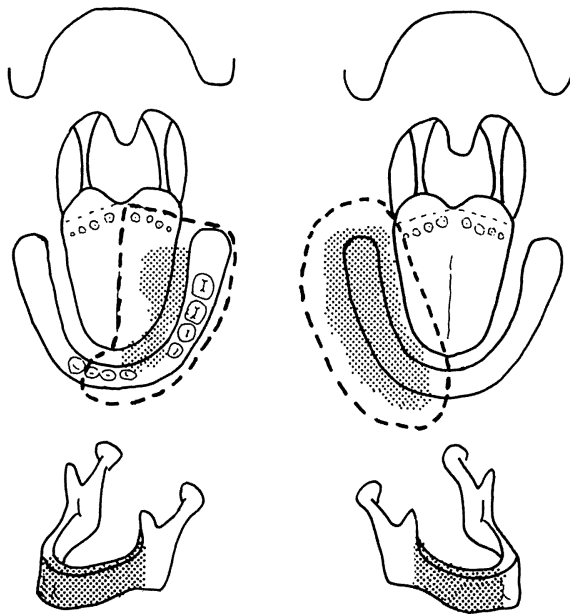

症例 2

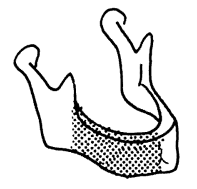

症例 3

図 1 各症例の腫瘍範囲と切除範囲

腫瘍範囲：点状に示した範囲.

切除範囲：口腔では破線，下顎骨では点状に示した範囲. 
1 月 12 日まで ${ }^{60} \mathrm{Co}$ 外照射 $40 \mathrm{~Gy}$ を行った後, 平成 5 年 2 月 3 日, 軟口蓋 - 側壁半側切除, 舌根部分切除, 舌頓 粘膜部分切除, 筋突起より 3 までの下䫇骨区域切除, 右頸部郭清, 腹直筋皮弁 $(8 \times 12 \mathrm{~cm})$ に上る咽頭口腔再 建叔よび遊離第 6 胁骨による下顎再建 $(10 \mathrm{~cm})$ を行った （図 2 ）。微小血管吻合の donor には, 動脈は頸横動脈, 静脈は外頸静脈を用いた. 移植肋骨は, チタ二ウム下顎 再建用プレート (LEIBINGER 社製)にて固定した(図 3 ). 術後経過は良好で，同年 4 月 3 日退院したが，ま もなく右肺上葉辺縁に転移が発見され, 他院呼吸器外科 にて胸腔鏡下切除をらけた。原発部に関しては，再発な く下顎骨の状態も安定している(図 4 )。やや皮弁が大き く，下䫇関節突起周辺を操作しているためか軽度の開口 障害があり, 軟菜食を摂取している。話機能は広瀬案基 準1)で， 5 点である.

症例 2.55 歳, 男性.

舌癌 $\mathrm{T} 3 \mathrm{~N} 0 \mathrm{M} 0$

平成 5 年 12 月初め頃より, 掑食時の口内痛めるも放置,

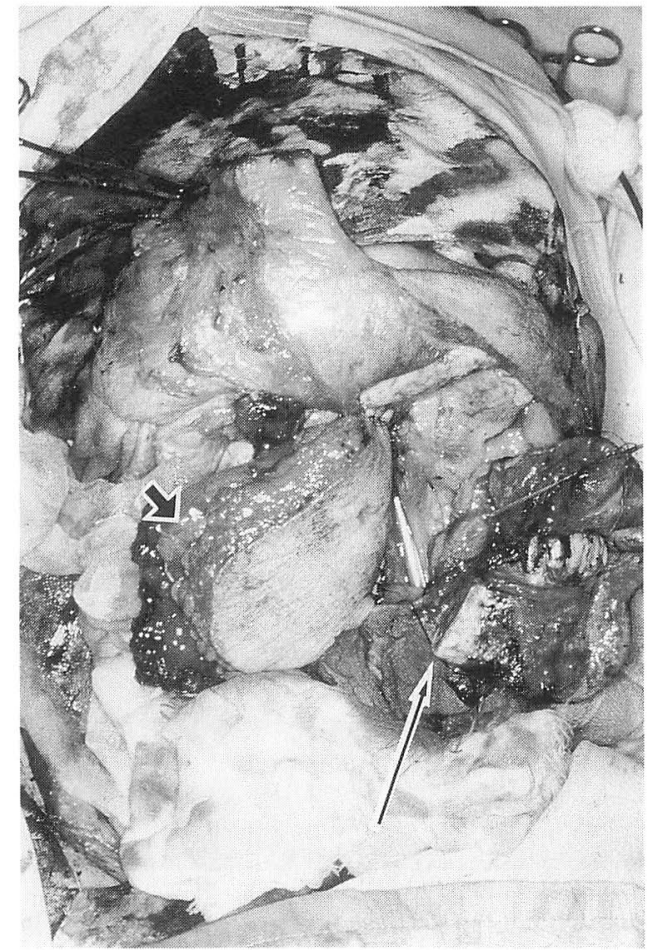

図 2 症例 1 の手術所見 (下顎区域切除後の再建中の状態) 小矢印：軟口蓋再建中の腹直筋皮弁を示す. 大矢印 : 下頂骨 3 断端. 残存舌根に系を掛け牽引している.

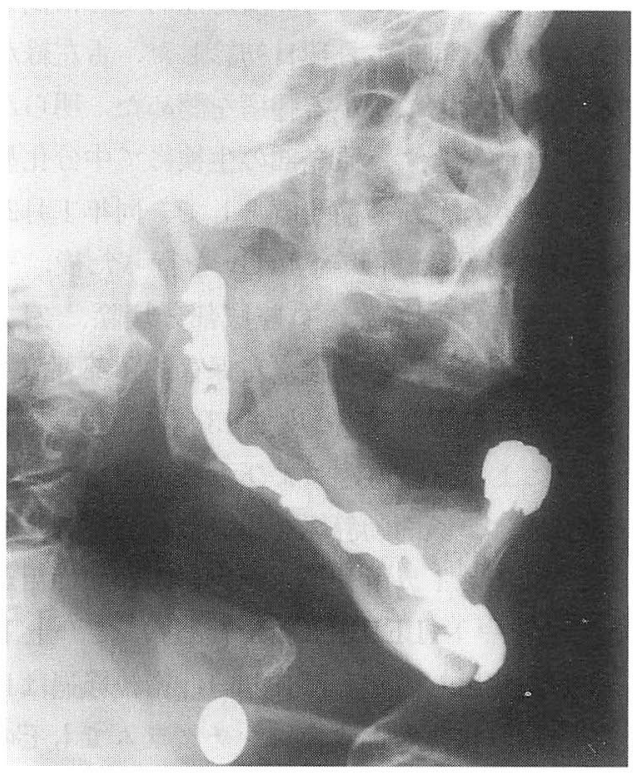

図 3 症例 1 の下顎再建後のX線像側面

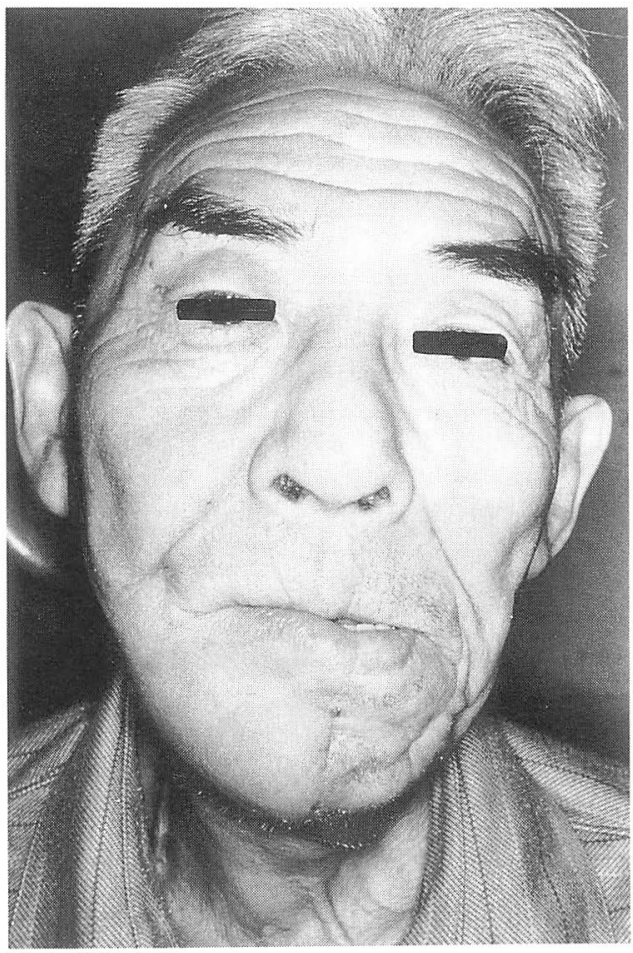

図 4 症例 1 の術後顔貌 
平成 6 年 1 月他医受診にて舌の潰瘍性病変を指摘され当 科に紹介された. 同年 1 月 12 日初診した. 舌左縁から舌 腹, 口腔底, 下歯肉にかかる腫痬を認めた。明らかな頸 部リンパ節は触知せず，原発部の生検にて中分化型扁平 上皮癌と診断された. 術前治療として, 同年 1 月 20 日よ り 2 月 15 日まで ${ }^{60} \mathrm{Co}$ 外照射 $40 \mathrm{~Gy}$ を行った後, 平成 6 年 3 月 9 日, 舌半側切除, 口腔底部分切除, 2 上り左 下顗角までの下顎骨区域切除, 左保存的頸部郭清, 右上 頸部郭清, 遊離肩甲骨皮弁(皮弁 $13 \times 7 \mathrm{~cm}$, 骨弁 $7.5 \times 3$ $\mathrm{cm}$, 図 5 )による口腔再建拈よび下靧再建を行った。微 小血管吻合には，顔面動静脈を用いた。肩甲骨は㲊部の 弯曲形成のため，1 カ所骨切りを行い，㴿顔面用チタ二 ウムミニプレート(LEIBINGER 社製)にて，上下 2 カ 所化計 3 個を使用し固定した(図 6 )。術後経過は良好で あり，下㖽骨の状態もよく骨シンチグラムでもその生着 は確認された，義歯の装着はまだ行わず，軟菜食で経過 をみている(図 7 )。会話機能は広瀬案基準で， 8 点であ る.

症例 3.65 歳, 男性.

下歯肉癌 $\mathrm{T} 4 \mathrm{~N} 1 \mathrm{M} 0$

平成 5 年 4 月頃上り, 口内痛あるも放置, 下顎の腫脹

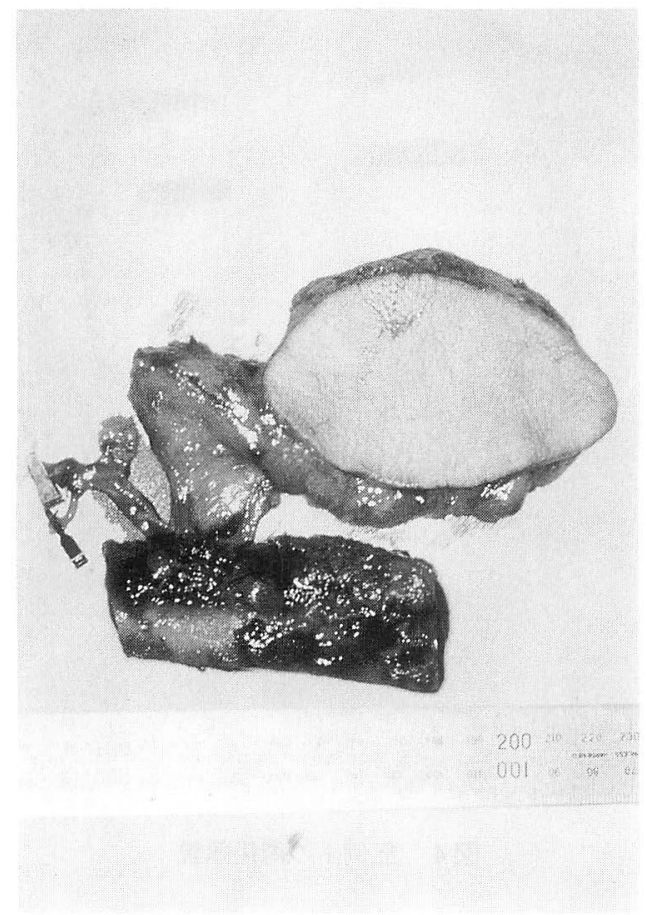

図 5 症例 2 の肩甲骨皮弁

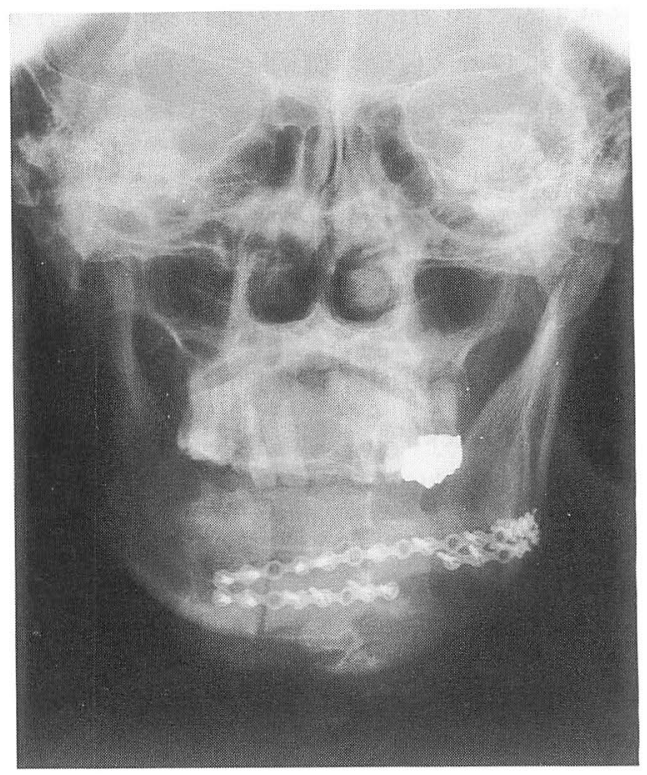

図 6 症例 2 の下顎再建後のX線正面像

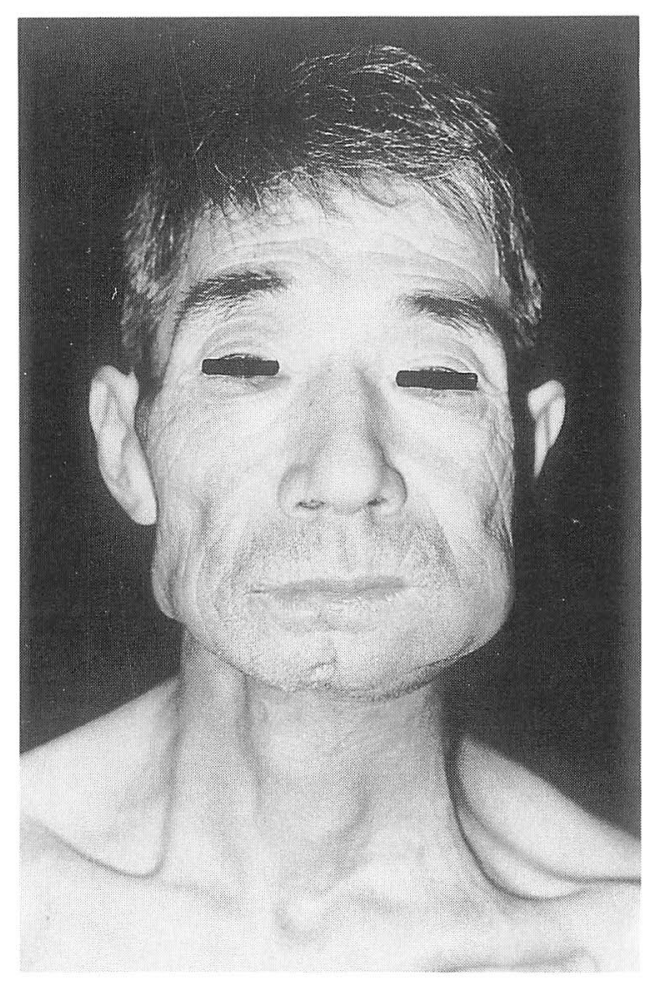

図 7 症例 2 の術後顔貌

があり義歯が安定せず，歯科にて義歯の調整を数回にわ たり行っていた．その後当院に他疾患で受診した際に下 
顗部の腫脹を指摘され，当科へ紹介された. 平成 5 年 5 月初診時, 右下顎部は大きく板状に腫脹し，軽度の開口 障害を伴っていた，腫脹部は，一部顎下部皮膚と癒着を 認めた。しかし口腔内には，明らかな腫瘍や潰瘍などは 認められなかった。CTにて，下顎骨に一部すでに浸潤 を認め, 顎下部から口腔底に広がる腫瘍が確認された。 㴿下部以外の頸部リン八節は触知せず，原発部の針生検 にて中分化型扁平上皮癌と診断された。術前治療として 同年 6 月 11 日上り 7 月 8 日まで ${ }^{60} \mathrm{Co}$ 外照射 $40 \mathrm{~Gy}$ 扮よ び，7月15日上り化学療法 (1 日目 CDDP $100 \mathrm{mg}, 2$ 5 日目 5 -FU $1000 \mathrm{mg} \times 4)$ を 2 クール施行した. 平成 5 年 8 月 20 日, 舌部分切除, 口腔底部分切除, 1上り右 下頡角までの下顎骨区域切除, 頸部皮膚合併切除, 右保 存的頸部郭清, 左上頸部郭清を行った。再建については, 肝硬变, 食道静脈瘤破裂などの既往があるため, 時間の 要寸る遊離再建や骨移植はせず，大胸筋皮弁 $(12 \times 5$ cm)を 2 島状にして口腔扣よび頸皮を再建し，下㴿につ いては，チタニウム下顎再建用プレート (LEIBINGER 社製)にて架橋のみを行った(図 8，9）。との際，1 回 目の再建では圧迫による皮弁循環不全を恐れ，プレート を上にして皮弁を縫合したため，プレートが，口腔内縫 合部より露出してしまい，術後 7 日目に再手術を行った。 2 回目では，プレートを皮弁で巻き込み，また死腔が出 来ないように筋体の一部とプレート間を吸収糸で固定し た. 摘出物の病理組織検査にて, 歯肉部原発と考兄られ た. その後の経過は順調で, 退院し外来経過観察中のら ち大腸癌, 腎癌が発見され, また転移性の肺癌, 骨転移

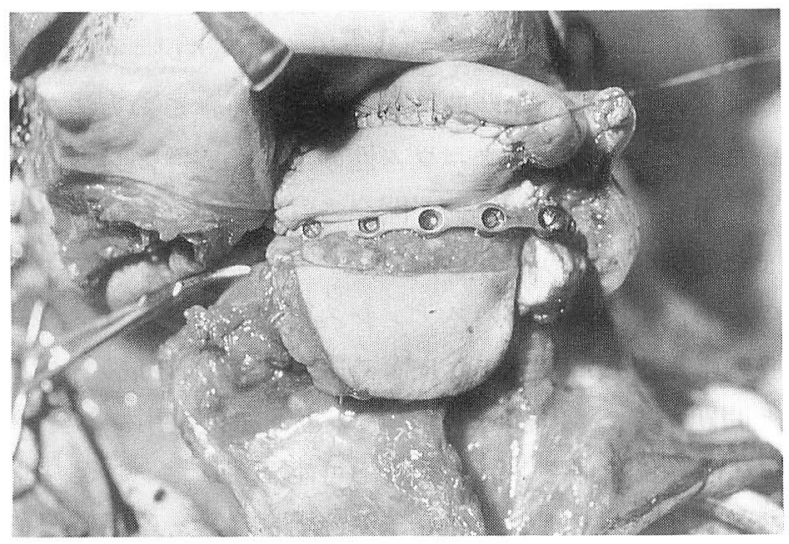

図 8 症例 3 の術中所見

下顎プレートの上下に 2 島状にした大胸筋皮升を残存舌 に縫着中.

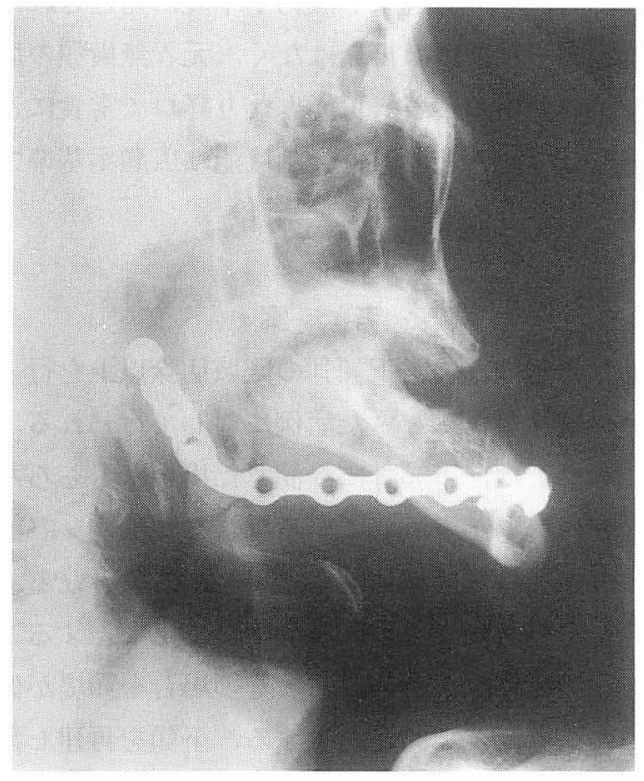

図 9 症例 3 の術後 X線側面像

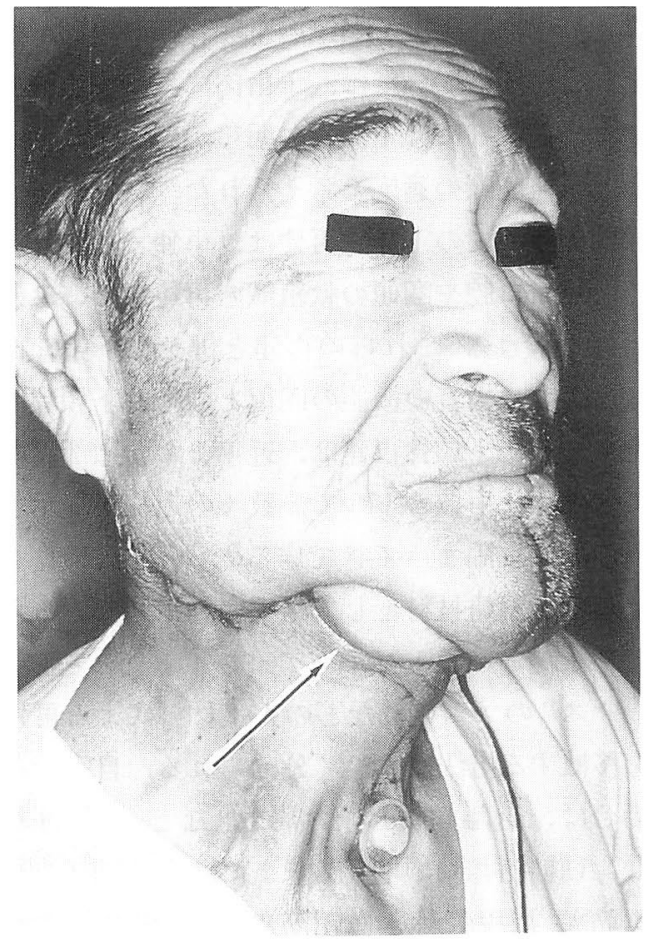

図10 症例 3 の術後顔貌 矢印：頸皮再建部 
(原発は何れか不明)を来し，約 1 年後に死亡された。こ の間口腔内や頸部には再発はなく, 元々無歯靧の症例で あったが，義歯の装着も可能となり経口で常食に近い食 物を摂取していた(図10)。会話機能は広瀬案基準で，9 点であった。

\section{考案}

下罘骨再建は，通常下靧骨の区域切除以上を行って下 顎骨の連続性がなくなった症例に対して行われる．頭頸 部癌に括いては，下頧骨に浸潤した場合はもちろん，下 歯肉などに腫瘍が浸潤している場合や頸部リンパ節の状 態により下顎骨を区域切除する場合が対象となる. 通常 の舌癌や口腔底癌では, 区域切除まで必要とすることは 少なく, 辺縁切除が行われる. その場合も顎堤が低くな り義歯の装着などで問題が生ずる．下顎を再建した場合 ではさらに，咬合のずれも起こり，なるべくであれば下 顎骨の連続性は残して扣きたいところである。しかしな がら近年の再建手術の進歩により下䫇の再建はより安全 に可能となり，下顎骨を区域切除せざるを得ない症例で より積極的に試みられるよらになってきている，本症例 のうち症例 1 では, 中咽頭癌であるが臼後三角部への腫 瘍浸潤と術中に顎下リンパ節の下顎骨への浸潤が疑われ たこと, 症例 2 においては, 下歯肉に浸潤する腫瘍であ ったこと, 症例 3 では下顩骨に明らかに浸潤していたこ とにより区域切除の適応と考学られた。

頭頸部癌手術での下顎骨再建は, 単独で行われること はなく, 通常口腔や咽頭の軟組織の再建あるいは頸部皮 膚の再建を伴 ${ }^{22}$. これらの再建と併せた下顎骨再建の 目的は, 咀嚼や構音の機能の回復と同時に下龥顔面形態 の維持である. 下顎骨再建は, 近年まで頭頸部癌の再建 の中でも困難な手技の 1 つで, 数々の方法が提示されそ れぞれの評価も固まってきている2)がいまだ確立したも のではない，再建材料として諸家の利用しているものは 様々であるが，ハイドロキシアパタイト3)やアルミナ七 ラミックス4)のブロックなどの人工材料による再建と自 家骨を移植する方法に大きく分けられる．自家骨を利用 する場合は，遊離骨(肋骨5)，腸骨6)など），骨付き有茎 筋皮弁，(肋骨付き大胸筋皮弁または広背筋皮弁 $\left.{ }^{7}\right)^{5}$ 上

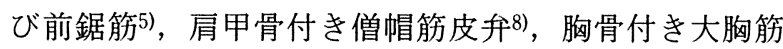
皮弁7)など)，あるいは血管柄付き骨(腸骨2), 肩甲骨9), 橈骨2)，腓骨10)など)で用いる. 患者の状態が悪い場合 は，骨移植をせずプレートで連続性を保つのみ(11)で経
過をみる場合や軟組織の再建のみで二次再建を考える場 合がある．遊離骨は感染に弱く骨吸収が必発であること などから人工歯根の植光込みには不利である12)。しかし ながら遊離腸骨移植でも移植後 1 年経過して後に人工歯 根を植え込むことも可能との報告もある13)。本症例のら ち症例 1 では, 軟口蓋から舌根, 舌の一部と広範囲の再 建のため, ある程度ボリュームが必要なため遊離腹直筋 皮弁を選択し, 骨については, 再建の時間短縮のため遊 離骨(肋骨)を選択した. 症例 2 では55歳といら年龄も考 慮し, 将来人工歯根など可能性を考党, 1 つの血管吻合 で口腔と骨の両者を再建できる肩甲骨皮弁を選択した。 症例 3 では, 最初の腫瘍がかなり大きく再発の可能性と, また肝硬変など合併症があることにより, 有茎皮弁とプ レートによる架橋のみで骨再建は行わなかった.

移植骨が生着する条件として, 頭頸部癌の場合は, 残 存する下顎骨の状態はよい状態とはいえないが, 移植骨 が，血管柄付きであれ，遊離であれ固定がしっかりして いることと, 血流のよい組織で被覆することが大切であ る14). 移植骨の固定には, 残存下顎の強勒な動きに負け ない強固な固定が必要で, 通常プレート固定される. 移 植骨の状態で, プレートを選ぶ必要があり，胁骨のよう な柔らかいものではミニプレートがよいら). 下䫓再建用 の大きなスクリューでは多少安定性が悪い，症例 1 では， 下頭再建用プレートを用いてしまい，一部固定したスク リューが利かないものがあり, 若干の不安定があったが, 術後特に問題は発生しなかった。 ミニプレートの場合に は十分残存下領骨に長く固定し移植骨にかかる力を分散 させるようにするのと上下に 2 個固定することで回転を 防ぐ必要がある15). 症例 2 では, 最初チタニウム下顎再 建用プレートを用いる予定であったが，プレートの非常 な硬さのため頋部の弯曲の形成が難しく，この方法を用 いた. しかし近々チタニウム性の柔らかい弯曲を形成し 易い下罘再建用プレートが開発されるとのことである. また症例 3 のように骨移植せずプレートで連続性を保つ のみの例では，以前のステンレス製では，プレートがロ 腔内に露出したり，また皮膚に露出したり，断裂したり と問題があった ${ }^{16)}$ が，チタニウム下靧再建用プレート により買位を保ち，義歯装着も可能となった。ステンレ ス製に比較してチタンプレートの場合は，その組織親和 性のため露出瘦孔の率が低い上うである17)が，長期的 には露出がないか評価はまだ不明である。この場合には 必ずプレート自体を口腔再建に使用する材料でくるみ死 
腔をなくす必要がある18).

術後の機能障害を防ぐためには，顎位を再現すること にあるが，口腔内も再建の必要のある例では，下龥骨切 除前にプレートの仮固定により行う，咬合の再現が重要 であるが今野ら ${ }^{19)}$ は，下顎骨下縁が数ミリでも保存可 能であるならこの上に移植骨を执く on-lay bone graft を症例により行っている，咀嚼機能としては，残存舌の 動きが大変重要であり，また残存歯牙の状態で義歯が装 着可能かあるいは人工歯根などを植え込めるかなどによ る. 2 次再建の場合はいろいろと問題がある．瘢痕拘縮 のため十分な機能回復は困難になる5 ${ }^{5}$. 舌亜全摘以下の 切除範囲の場合, 再建後咀嚼を行う上で, 残存舌の動き をじゃませず，また残存歯があり義歯が装着できそらで あれば bulky な再建は好ましくなく，前腕皮弁が最適20) で当科でも下顎再建を伴わない症例に数例行っている. 摂取できる食物形態は, 開口, 靧位の状態と義歯の装着 とその安定性に関係するが，理想的には移植骨に人工歯 根を植え込みしっかりとした咀嚼を行らことがよいと思 われる。しかしまだこれらの術後機能を満足いく状態に するのは，なかなか難しい点がある。また患者の状態， 年龄により, 本人の欲求度も違らので, 個々の症例に合 わせて考えていく必要があると思われる，自験例に拈い ては, 症例 1 ではやや開口障害があり，会話咀嚼とも， 残存舌の動きが顎下リンパ節の状態で患側の舌下神経を 切除したため, 機能的にはやや不満足である. 症例 2 で は，残存舌の動きはよく，まだ観察期間は短いが，会話 機能, 開口もよくほぼ満足できている。この症例のよう に下顎の欠損が $13 \mathrm{~cm}$ 以下であるならば，口腔軟組織 の再建も含め, 肩甲骨皮弁が有用との報告が近年多く, さらに安全に骨切りして弯曲を形成するためには，肩甲 骨下角に入る角枝を含める2122) 方がよい上らである。

移植された肩甲骨には人工歯根植兄込みも可能である23) が厚さが体格により十分でない場合は不可能な場合もま たある12). 症例 3 は, 患側の舌下神経は切断したが, 舌 をほぼ残せたのと術後に義歯を装着できたので機能的に も非常によかった. 患者の予後を考光ると, 必要十分な 再建が出来たと考兄ている.

整容的再建については, 下䫇骨前方の欠損では, 舌喉 頭の下垂のため嚥下が困難になり，必ず再建を要するが， 弯曲の形成が難しく, 移植骨は骨切りをして弯曲をでき るだけ再現することになる．前述した角枝を含めた肩甲 骨や腓骨などで安全な骨切りができ応用されている。下
顎骨角部体部では, 何れの方法を用いても再建は比較的 容易である15)。

基本的には, 切除時に同時下顎再建と人工歯根も出来 れば理想であるが，このように実際には下頂骨再建方法 は，患者の状態扣よび年龄により選択されるべきと考兄 る. 若い方であれば，人工歯根植光込みを考慮して，肩 甲骨皮弁または血管柄付き腸骨，年齢的に咀嚼が軟菜程 度でよいなら，遊離骨(肋骨，腸骨)，予後不良例ではチ タンプレート架橋のみで行う．顎堤の再建は何れの場合 も義歯装着のため重要となるが困難なことが多い，但し 可動する舌がない場合，顎関節を含む切除や下顎骨亜全 摘以上の場合では, 現在の方法では機能の改善は困難で ある。

$$
\text { まとめ }
$$

1 ) 頭頸部癌切除に伴う下顎再建に異なる再建法を用 いた 3 例(遊離肋骨, 肩甲骨皮弁, チタンプレート)を報 告した.

2) 下顎再建は, 理想的には人工歯根が可能な血管柄 付き腸骨，肩甲骨による再建が望ましいが，患者の状態， 年齢, 予後と Quality of Life の面からもその方法を選択 する必要があり, 咀嚼, 與下, 構音および整容的な改善 を図る必要がある。

\section{参考文献}

1) 日本頭頸部腫瘍学会編：頭頸部癌取扱い規約. 101頁, 金 原出版, 東京, 1991.

2 ) Swartz WM and Banis JC : Mandibular reconstruction. Head and neck microsurgery. pp 187 236, Williams \& Wilkins, Baltimore, 1992.

3 ）瀬戸皖一, 松浦正朗 : 自家骨ならびに人工骨による下㖽再 建とその問題点. 形成外科 $34: 5 \sim 14,1991$.

4 ）橋場友幹, 高橋 衛, 佐藤重信, 他: アルミナセラミック 人工骨による下頸骨再建 一下頸骨半側切除症例 3 例への 応用一. 日外誌 $35: 1487 \sim 1495,1989$.

5 ）鎌田信悦, 川端一嘉, 井上哲生, 他：下頸骨区域切除に対 する再建術. JOHNS 6 : 303 314, 1990.

6 ）松浦正朗, 瀬戸皖一, 高田典彦, 他 : 自家遊離腸骨移植に よる下顎再建とその術後経過について，日口外誌 34 ： 1366 1381, 1988.

7 ）峯村俊一, 武田 進, 高橋基浩, 他: 骨付き大胸笳皮弁, 広背筋皮弁に上る口腔癌切除後の下㴿再建. 口腔腫瘍 $3:$ 223 232, 1991.

8）木村 洋, 中村 正, 戸島 均, 他 : 肩甲骨棘付き僧帽筋 
皮弁による下顎再建手術. 耳鼻臨床 $84 ： 1429$ 1436, 1991.

9 ) Coleman JJ and Sultan MR : The bipedicled osteocutaneous scapular flap; a new subscapular system free flap. Plast Reconstr Surg 87 : 682 692, 1991.

10) Hidalgo DA : Fibula free flap; a new method of mandibule reconstruction. Plast Reconstr Surg $84: 71 \sim 79$, 1989.

11）三村 保, 福原尚子, 宅間政次, 他: AO プレート単独使 用による下顎再建 -9 症例の経過観察一. 日口外誌 35 : 510 518, 1989.

12）中塚貴志, 波利井清紀, 山田 疜, 他: 癌切除に伴ら下顎 再建術の検討. 日形会誌 $11: 283 \sim 298,1991$.

13）吉賀浩二, 高田和彰：下䫇の再建. 頭頸部腫瘍 $19: 12 \sim 16$, 1993.

14) Boyd JB : Osteocutaneous free flap options in oral cavity reconstruction. Operative Techniques in OtolaryngologyHead and Neck Surgery 4 : 104 114, 1993.

15）小村 健：下㴿骨切断・切除・固定ならびに欠損修復. JOHNS 5 : 135 142, 1989.

16) Gilbert RW and Dorion $D$ : Management of the failed mandibular reconstruction plate. Operative Techniques in Otolaryngology-Head and Neck Surgery $4:$ 159 164, 1993.
17）中塚貴志, 海老原敏, 吉積 隆, 他 : 頭頸部癌切除後の下 顎再建に打けるチタン製下顎再建プレートの使用経験. 日 頭蓋頸顔面外会誌 $8: 96 \sim 97,1992$.

18) Clifford A and Davidson J : Free and pedicled flaps on metal plates. Operative Techniques in OtolaryngologyHead and Neck Surgery 4 : 155 156, 1993.

19）今野昭義, 花沢 秀, 寺田修久: 口腔癌切除後の再建術と 術後機能. JOHNS $6: 323 \sim 330,1990$.

20）田原真也, 天津睦郎, 牧野邦彦, 他 : 舌 - 口腔底 -下顎骨 の再建. JOHNS $10: 59 \sim 65,1994$.

21）古田 淳, 松尾 清, 広瀬 毅, 他: Angular branch を 使用した肩甲骨による下顎骨再建の経験. 形成外科 35 : 837 843, 1992.

22）西川邦男: 肩甲骨皮弁による下㴿骨広範囲切除後の咀嚼能 再建. 耳鼻 $40: 663 \sim 674,1994$.

23) Tahara S, Suzuki T, Kikui T, et al : Mandibular reconstruction with subsequent denture implantation. $\mathrm{Br} \mathrm{J}$ Plast Surg 42 : 344 346, 1989.

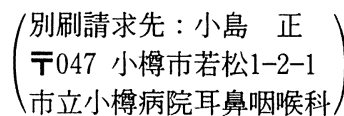

